\title{
THE CHINESE FOOTBALL DEVELOPMENT PLAN: SOFT POWER AND NATIONAL IDENTITY
}

\author{
E. F. LEITE JÚNIOR*, C. RODRIGUES \\ University of Aveiro, Portugal \\ emanuel.leite.junior@ua.pt*
}

Received 09/03/2017 - Accepted 20/09/2017

DOI: $10.15628 /$ holos.2017.5750

\begin{abstract}
In April 2016, the People's Republic of China (PRC) launched the "football development plan in the medium and long term (2016-2050)." The Chinese Government's goal is clear: making the Asian country a worldwide football superpower. This article will show how the Chinese strategy is organized in its three stages, with commitments and goals to be reached at the end of each one of them. Including the President Xi Jinping "three World Cup dreams" audacious plans: to qualify for another FIFA World Cup edition, host a World Cup edition and, finally, win a World Cup by 2050 to thus consolidate the country's football power in the most popular sport on the planet. The article also intents to demonstrates how the Chinese state induces private investment in football and sports industry. Showing that the large Chinese conglomerates have beeing collaborated in a crucial manner so that the government achieves the objectives outlined in its plan. And while China is moving towards the development of the most popular sport on the planet, the article brings to the theoretical discussion issues such as soft power and sport's influence, especially football, in the identity and national pride. Brought to a conclusion that the Chinese state has taken advantage of the football popularity to exercise 'soft power', strengthening diplomatic ties and placing the country in the Asian and worldwide context, but also to reinforce their people sense of national identity. For this, the article resorts to the bibliographic review, comparative study, in addition to analyzing the football development plan.
\end{abstract}

KEYWORDS: development, football, China, national identity, soft power.

\section{O PLANO DE DESENVOLVIMENTO DO FUTEBOL CHINÊS: SOFT POWER E IDENTIDADE NACIONAL}

\section{RESUMO}

Em abril de 2016, a República Popular da China lançou o "Plano de desenvolvimento do futebol a médio e longo prazo (2016-2050)". A meta do Governo é clara: fazer do país uma superpotência do futebol mundial. Este artigo vai mostrar como se organiza esta estratégia. Em suas três etapas, com compromissos e metas a serem alcançados ao fim de cada uma delas. Que incluem os audaciosos planos dos "três sonhos da Copa do Mundo" do presidente Xi Jinping: voltar a disputar uma Copa do Mundo FIFA, sediar uma edição do torneio e, por fim, conquistar um Mundial, consolidando, assim, o país como uma potência global. O artigo pretende, também, demonstrar como o Estado chinês induz o investimento privado no futebol e na indústria desportiva. Mostrando que os grandes conglomerados chineses têm colaborado de forma primordial para que o Governo atinja os objetivos traçados em seu plano. E enquanto a China caminha na direção do desenvolvimento do futebol, o artigo traz à discussão teórica questões como 'soft power' e a influência do desporto, em especial do futebol, na identidade e no orgulho nacionais. Conclui que o Estado Chinês tem tirado proveito da popularidade do futebol para exercer o 'soft power', reforçando laços diplomáticos e inserindo o país no contexto asiático e mundial, bem como se aproveita para fortalecer a afirmação do senso de identidade nacional. Para isso, o artigo recorre à revisão bibliográfica, estudo comparado, além de analisar o plano de desenvolvimento para o futebol.

PALAVRAS-CHAVE: desenvolvimento, futebol, China, soft power, identidade nacional. 


\section{INTRODUCTION}

Throughout the 20th century sports, as a cultural phenomenon and mass spectacle that it is, was consolidated as a manifestation of international dimension. As reminds us the historian Eric Hobsbawm (1991), it was during the period between the two world wars that sports has become definitely an "expression of national struggle, with athletes representing their states or nations, fundamental expressions of their imaginary communities" (p. 171). So it is impossible to dissociate the history of modern sports from elements such as national pride, international prestige and diplomacy (Cha, 2016).

In the context of the international competition high performance sports, thus, have the ability to reaffirm the national identity, while it can be used as a tool for promoting the country's image - both in the pursuit of international acceptance (Allison \& Monnington, 2002), as in the establishment of international relations through the so-called 'soft power' (Brentin \& Tregoures, 2016; Giulianotti, 2015; Samuel-Azran, Yarchi, Galily, \& Tamir, 2016).

It was not by accident, therefore, that since returning to the International Olympic Committee in 1979, China established an "Olympic strategy", which was implemented from 1980 on (Hong \& Zhouxiang, 2012d). Introduced by the Ministry of Sports, the strategy was deepened after the bad results in the Seoul Games (1988). In the years 1990 and 2000 with the implementation of elite sport system that Chinese named 'Juguo Tizhi' (举国体制 in Chinese Mandarin), which in English means 'the whole country support for the elite sport system'. This system aimed to channel the maximum resources possible for the Olympic Games. The Chinese government, in fact, always made sure to emphasize the political importance of the country's Olympic project success (Hong \& Zhouxiang, 2012b). The Chinese strategy worked. The culmination of the high investments system in elite sport took place in the Beijing 2008 Olympic Games, when China won 51 gold medals against 36 of the United States.

However, the success of the Chinese Olympic sports never came close to be replicated in the most popular sport in the world: football. According to FIFA, the historical origin of football lies in Ancient China and in the practice of cuju (蹴鞠) (Simons, 2008, p. 46). The cuju (蹴鞠), that literally means "kicking a ball", dates back to the times of the Han Dynasty (206 BC - 220 AC). Liu Bang (刘邦 256 BC - 195 BC), the founding emperor of Han Dynasty, was a big cuju (蹴鞠) fan. Simons (2008) says that watching this ancient football was the favourite hobby of Han's emperors and also became a popular national pastime among both elites and commoners.

Centuries later, the popularity of football further soared during the Tang Dynasty (618907). According to Simons (2008, p. 47 e 48), the innovation in the way of manufacturing the ball (no longer filled with feather or hair, but air, which allowed the ball to be bounced high) helped players to improve their skills making spectators to enjoy even more the game. Historical records demonstrate that cuju was also quite popular during the Song Dynasty (960-1279), the technologically most advanced era in the ancient China. It is from this time the creation of the first cuju club (Simons, 2008, p. 48).

It is not clear when football is no longer practiced in China. It is believed that it was during the Qing Dynasty in the 17th century, with the occupation of China by Manchus. A few centuries later, the modern game, codified in England in 1863, reappears in China in the 19th century. "The 
first documented game in China using the rules of the Football Association was played in 1879 in Shanghai" (Simons, 2008, p. 157).

Football would only become professionalized in the "Middle Kingdom" in the 1990s and was in the wake of the great economic reform that the country went through in that period. Under the leadership of Deng Xiaoping, China entered the era of "market socialism" and China's elite sports system underwent a thorough restructuring to suit the new reality. Football was the pioneer in sports reform. Thus, in 1994, the first professional championship of the country appeared. The competition experienced a brief period of popularity, but faced various adversities. Mainly the successive corruption scandals and match-fixing with vicious results. This made the credibility of the competition fade, causing sponsors and viewers to lose interest. After a few unsuccessful attempts by the Chinese authorities to combat football fraud, 2011 is seen as the paradigm of a new phase of professional football in the country (Hong \& Zhouxiang, 2013).

Despite being the first sport to be professionalised in China in the wake of the economic reform process by which the country went through in the early 1990s - "market socialism" (Hong \& Zhouxiang, 2013) -, and its development in recent years, the Chinese football has represented not only a disappointment, as sometimes exposes the feeling of national pride to humiliation as the 5 to 1 defeat to Thailand in their own territory in June 2013 (Giulianotti, 2015; Hong \& Zhouxiang, 2013; Tan, Huang, Bairner, \& Chen, 2016).

At the end of the Beijing 2008 Olympic, the then Chinese President Hu Jintao ordered actions to be taken for the country to move forward from "a country of major sporting events to a sports world power" (Tan et al., 2016). This statement as a sporting power, of course, means the conquest of international respect in the most popular sport of all: football.

Known for his enthuasiam for football the current Chinese President Xi Jinping nurture "three World Cup dreams": participate in the World Cup; host the World Cup and to win the World Cup (Tan et al., 2016).

To make China into the future world football power, the Chinese government launched in April 2016 the "football development plan in the medium and long term (2016-2050)."

This article aims to analyze the role of the Chinese state in the promotion of sports policies, particularly in football, and its contribution to the affirmation of national identity as well as its relevance in the field of international diplomacy, in promoting the country's image vis-a-vis other nations and contributing to the establishment or strengthening of relations with other states "soft power".

\section{THE AMBITIOUS CHINESE PLAN}

The global sports industry moved around \$ 1.5 trillion in 2015, according to Plunkett Research estimates. US $\$ 498.4$ billion only in the United States (Plunkett Research, 2016). In its football development medium-term plan, the Chinese state sees the most popular sport on the planet as the driving force for the growth of the entire country's sports industry. Making the country into a powerhouse of world football, in the Chinese view, would be a way of contributing to the economy, society and culture development. The goal is that in five years the country's sport industry will generate $\$ 460$ billion (The State Council, 2016) and in 2025 to reach a value of around US $\$ 813$ billion (Sports, 2016). 
Currently ccupying 62nd in the International Federation of selections ranking Football FIFA (FIFA, 2016), Chinese football team was only present in a final edition of the World Cup: in 2002, at the World Cup played in South Korea and in Japan. With three defeats in three games and nine goals conceded and none scored, China flied home early from the event. The Chinese national football team failed to qualify for FIFA World Cup 2018 that will be played in Russia.

Aware of the hard work that lies ahead in promoting the country's football development, the Chinese government has established three stages in the medium to long term.

- Until 2020: 20000 specialized football schools, 70000 football fields, between 30 to 50 million primary and secondary students practicing the sport.

- Until 2030: 50000 specialized football schools, male Chinese team to be one of the best in Asia, and the women's team established as "world class".

- Until 2050: first step selection in world football (male) in the FIFA's top-20 ranking, having hosted and won the World Cup.

Recently, according to the official newspaper of the Chinese Communist Party The People's Daily, "Chinese sports authorities have upped their objectives to try to fast-track football development": instead of 20 thousand football schools by 2020, they now expect to achieve this goal by the end of the current year; and instead of 50 thousand football schools until 2030, the Chinese authorities raised that bar to 2025 (People's Daily, 2017).

This is because in order to get to the top of the world football, you need something basic: people who practice this sport in the country so that it is possible to select the best 23 athletes every four years to be competitive in the World Cup (unlike what happened when their national team visited South Korea in 2002). They need to popularize football. To make this sport a daily practice of the children and young people of this country. To create, therefore, a soccer culture among its people. In Europe, which exported the practice to the world, "the federations arose because there were players who formed teams and teams that became clubs that sought power in unity" (Simons, 2008, p. 221).

And education can play a very importante role in this. The football development plan is well aware of this. For this reason, it aims to promote the strengthening of grassroots football and community football, talent training, increasing the scale of youth participation in football, developing football schools to promote interest and cultivating fans (China, 2016, pp. 3, 4, 5).

That is also why the plan gives special attention to the Chinese educational system. To greatly increase the scale of teenagers football participation the plan establishes that there must be an improvement of the level of physical education teachers in order to absorb core football teachers into the national training program for primary and secondary school teachers and also to adhere to combination sports skills and cultural education (China, 2016, 6).

\section{THE STATE AS A GUIDE}

To meet these objectives, the Chinese state counts on the private sector participation in implementing the plan. It's the same model to be followed since the "Guide to sports industry 
development acceleration" was adopted. That is, the government doesn't intervene directly in the sports market, only guiding and supporting the industry development, creating a structure that allows the coexistence of various properties and competitiveness in the market and may also participate collaboratively in the industry promotion (Zhan, 2013).

In terms of 'top-down' investments, the Chinese private sector has responded in a very positive way to the state actions. Only in the winter transfer window of 2016, Chinese clubs spent \$298 million, according to the FIFA Transfer Matching System (TMS, 2016). In the 2016 summer window, Shanghai SIPG paid around $€ 55$ million to Russia's Zenit to sign the Brazil international forward Hulk, who became one of the best paid players in world football.

Since 2011, private groups such as Dalian Wanda Group and Evergrande Real Estate Group have made investments in the country 's football (Tan et al., 2016). Wanda Group has made available RMB 500 million for three years for the Chinese sports restructuring. More recently, the Wanda Group acquired 20\% of Atlético Madrid (Spain) - also signed with the colchonero club an agreement to be the naming right of their new stadium - and became Infront Sports \& Media AG owner, one of the most respected sports marketing companies in the world and which has as one of its clients nothing less than FIFA. The Dalian Wanda is also, since 2016, a major sponsor of FIFA (Chadwick, Widdop, \& Parnel, 2017).

On the other hand the Evergrande Real Estate Group, owner of the current Chinese sixtime Champion in a row Guangzhou Evergrande (coached by Luiz Felipe Scolari), will give, for 10 years, RMB 100 million annually to a poverty alleviation fund, with part of the grant being used to fund talented young people without financial conditions. The club also have a football school in partnership with Real Madrid (Evergrande Football School)

Owner of 50\% stake in Guangzhou Evergrande, the Alibaba Group has signed a deal to sponsor the next six Olympic Games. The group "will also provide technology services to the games organisers, and will establish the Olympic Channel, a new digital television service intended to promote the games to younger sports fans" (Ahmed, 2017). Since 2016, The Alibaba Group negotiates with FIFA to become one of its major sponsors (Reuters, 2016).

Not only these groups have been investing in world football. The company Suning, owner of Jiangsu Suning, acquired Inter Milan in June 2016, one of the Italians biggest clubs (Jourdan, 2016). In April 2017, AC Milan, seven times European champions, has been bought by Chinese investors. Rastar Group from Guangdong province paid about 17 million euros to buy $54 \%$ of the shares of the Catalan club Espanyol, while in 2015 CEFC China Energy Company bought $59.97 \%$ Slavia Prague, Czech Republic The conglomerate Fosun signed in early 2016 a partnership with the Portuguese Jorge Mendes' Gestifute players agency that has Cristiano Ronaldo among its intermediateds (Jing, 2016). Fosun also owns Wolverhampton Wanderers from England and is investing 10 million euros in the Portuguese club Rio Ave.

It is speculated that the China Everbright state group is likely to purchase Liverpool, the second greatest champion of England. Chadwick warns, however, that such deal could generate a conflict. This is because the state - owned China Media Capital also owns 13\% of Manchester City and in England the owners of more than $10 \%$ of a clubs' shares may not have $9.9 \%$ of another (Chadwick, 2016). 
In terms of 'bottom-up' investments, there are, for example, the already mentioned Guangzhou Evergrande football academy, in partnership with Real Madrid. And the Chongqing Sports Campus.

\section{SPORTS AND SOFT POWER}

Joseph Nye defined that "power is the ability to influence others to achieve the results you want, which can be done through coercion, payment or attraction" (Nye, 2012). In contrast to the "hard power" of coercion (military force) or payment (economic strength), which are able to make others change their position, Nye conceptualized that you can get results without having to resort to threats or financial exchanges. It was what he called 'soft power'. It would be the power of seduction over the other. "A country can get the results wanted in international politics because other countries - admiring its values, emulating its example and aspiring to its level of prosperity will want to follow him" (Nye, 2004).

Sports can be a very useful tool in the exercise of soft power (Brannagan \& Giulianotti, 2015; Brentin \& Tregoures, 2016; Giulianotti, 2015; Korneeva \& Ogurtsov, 2016; Samuel-Azran et al., 2016). The recent history of China and sport in the country is full of examples of how the Chinese state capitalize on this feature in terms of diplomacy.

By winning the Nationalist Party (KMT) in 1949, the Communist Party ended the civil war and established the People's Republic of China. Since then, the Chinese government has been using sports for its international relations. Since the country's "sports Sovietization" in the 1950s (fundamental in establishing contacts with the Soviet Union and Eastern European countries), through the Games of the New Emerging Forces (GANEFO), by the "ping pong diplomacy" (which allowed the rapprochement with the United States in a period of tension in Sino-Soviet relations) to the Olympic strategy and the quest for glory at the Olympics games (Hong \& Zhouxiang, 2012a, 2012c).

Hosting Beijing 2008 Olympic Games allowed China to show the world their development and enabled the country to stand as a world power - at the economic and sports levels. "The image of a highly modern nation, efficient and increasingly prosperous" (Giulianotti, 2015).

It is this demonstration of economic, technological and cultural strength, in our view, that integrates part of Chinese President Xi Jinping's "dream" to see his country hosting the biggest competition of the most popular sport on the planet: the FIFA World Cup. It would be the perfect opportunity to reaffirm the position of the country as a global power in the international arena, particularly in Asia. Besides, of course, to put the country once again in the eyes of foreign investors, business partners, tourists and other consumers (Giulianotti, 2015).

Still in the field of diplomacy, international relations and foreign trade, the Chinese football development plan can also serve as a way to bring the country closer to trading partners. It is what researcher Simon Chadwick draws attention regarding a possible alliance between China and Iran in the sports field, from the Chinese project "One Belt and One Road". What would not be a novelty, as Chadwick alludes, once the Chinese state-owned China Media Capital acquired $13 \%$ of the English club Manchester City, which is controlled by investors from Abu Dhabi. Such acquisition came after a high investment agreement between China and Abu Dhabi, in the oil and gas área (Chadwick, 2016). 
Giulianotti, however, draws attention to the risk of 'soft disempowerment', which is when "trying to get 'soft power' backfires, influence and prestige are shaken rather than expanded" (Giulianotti, 2015).

\section{SPORTS, IDENTITY AND NATIONAL PRIDE}

Hobsbawm, one of the most referenced theorist about nationalism, wrote that "the imagined community of millions seems more real as a team of eleven people with a name. The individual, even one that just supports, becomes the symbol itself of his nation" (Hobsbawm, 1991). As noted by Duerr, the historian uses the Benedict Anderson's term - "imaginary community" - to support the idea that people living in the same country are connected to each other, even without ever meeting each other. Which becomes latent when the national football team enters the field (Duerr, 2016). In another work, Hobsbawm goes back to highlight what he considers football catalyst power. "Practically since it acquired a mass audience, this sport [football] has been the catalyst of two forms of group identification: local (with the club) and national (with the national team, composed with the clubs players)" (Hobsbawm, 2007).

This helps us to understand what took nine million Dutch, about $60 \%$ of the Dutch population then, to the streets on a Tuesday night, June 21, 1988. The most popular celebration since the liberation of Germany in 1945 happened just after the Dutch national football team winning the German team by 2 to 1 in the UEFA Euro 1988 semi-final. The triumph on German soil made millions of young people - the generation that has never suffered from the German invasion was more effusive than the one who lived the dark period of war - to shout on public roads - "We took our bikes back" (German troops confiscated bikes during the occupation the Netherlands) (Ward, 2009).

In contrast, however, another study in the Netherlands questions the discourse that associates the need to increase investment in high competition sports to the growth of national pride and sense of national identification. Based on a public consultation conducted in the country in the summer of 2008, the effects on the Dutch people's national pride were measured from the sports results in sporting events and major events of that year: Euro 2008 (football), the Beijing Olympic Games, Tour de France (cycling) and Wimbledon (tennis). There were 300 respondents for each measurement (12 in total) in the period between May and October 2008. The authors concluded that there is no empirical evidence to demonstrate the existence of an intrinsic relationship between sporting success and the importance played by sport in a country when it comes to national pride, thus refuting the argument of those who advocate an increase in public investment in sport in order to win medals, as a mechanism of elevation of the national pride (van Hilvoorde, Elling, \& Stokvis, 2010).

This study diverges not only from the empirical evidence of the biggest Netherlands popular expression since the end of World War II (Ward, 2009), but also, for example, diverges from the analysis that the anthropologist Roberto Da Matta made regarding the importance of football in the formation of Brazilian national identity. When comparing Brazil with European countries and the United States, Da Matta notes that these had as sources of social identity consolidated institutions such as the constitution, the political system, the financial order, and the 
university system, while Brazil, in the absence of political and social structures, formed its identity from secondary sources such as carnival, samba, football and religion (as quoted in Lovisolo \& Soares, 2011).

Other authors, such as Cha, reinforce the idea that sports have been used in the construction of national identity. And the author gives the example of the Olympic team of the unified Germanies that in the 1956, 1960 and 1964 Games, despite all the differences and the Cold War atmosphere, played in competitions under the same flag (Cha, 2016). Germany, by the way, used FIFA World Cup 2006 to change their negative image because of the two World Wars and the Holocaust, at the same time that experienced a euphoric sense of nationalism (Kersting, 2007; Samuel-Azran et al., 2016; Ward, 2009).

It is no coincidence, therefore, that in their "football development plan in the medium and long term (2016-2050)" the Chinese state points out that "football is a sport of global influence" and that "the realization of the dream of becoming a football power"would be a clear demonstration of the" great rejuvenation of the Chinese nation "and a source of" national pride" (China, 2016).

To Giulianotti "football is one of the major cultural institutions, such as education and the mass media, which forms and consolidates national identities worldwide" (GIULIANOTTI, 2010, p. 42). This was the case of the Kosovo football team. When Kosovo's team entered the field of play for the first time on March 5, 2014, for a friendly match with the selection of Haiti, the feeling that their people had was as if, finally, their nation was recognized. And it was precisely football that gave the Kosovars a sense of international recognition of their national identity (Brentin \& Tregoures, 2016).

This feeling is in line with the Chinese proposal, that wants to "revitalize and develop football" for being "a burning expectation of the people," and adds that this is because this development "cultivates in people physical and psychological health and excellent culture" (China, 2016).

\section{CONCLUSION}

The launch of "football development plan in the medium and long term (2016-2050)" is a milestone in the history of not only football professionalization but all the sports industry in China. As stated, the Chinese state acted directly to induce the private sector to foster and develop the most popular sport in the world's most populous country, in order to increase the sports industry in the country.

But not only that. China wants to become a powerhouse of world football. Its president, $\mathrm{Xi}$ Jinping, dreams of returning to see the national team of his country - which is the same to say 'see his country' in the field of play (Hobsbawm, 1991, 2007) - in a FIFA World Cup edition. Xi wants more. He longs that China repeats the achievement of Japan and South Korea rivals. The Chinese presidente wants China to host football's biggest competition: the World Cup. As if all this was not enough, taking into account a national team that takes up only the 62nd place in the FIFA rankings, the Chinese president hopes of becoming a World Champion by 2050 , consolidating its position as a football superpower.

$\mathrm{Xi}$ isn't an ordinary person. He is probably one of the most powerful people in the world. And you can see how impressive is Xi's power measuring the great impact of his whim. It is 
amazing to see such a powerful country undertaking so much efforts to heed its leader will. One man's dream and hobby has become a nation's goal - and a private sector's duty.

For this, the Chinese state has launched a public policy strategy that aims to make football part of Chinese citizen's culture. In addition to acting directly, opening football schools, increasing hours of physical education classes (most notably football, of course), the Chinese government plan calls for cooperation from the private sector to also invest in developing the sport in the country.

As seen, the largest Chinese private conglomerates have responded to the call of its government, investing in the total sum values that already exceed billions of dollars - if we consider the millions signings of players and high-level foreign coaches in the Chinese Super League, purchases of big European clubs like the Milanese Internazionale and AC Milan, the percentage of clubs like Manchester City and Atlético Madrid, and partnerships with major international marketing and players agencies.

The goal of becoming a world football superpower, while sought, allows China to exercise soft power, through their diplomatic relations on behalf of football. As well as the goal to host the FIFA World Cup, aiming to repeat what was obtained with the organization of the Beijing Olympic Games in 2008.

All this contributes directly to China's national statement as a world power, which generates therefore the increase of Chinese people identity and national pride.

\section{REFERENCES}

Ahmed, M. (2017). Alibaba to sponsor next 6 Olympic Games. Retrieved January 19, 2017, from https://www.ft.com/content/b5e16726-de1e-11e6-9d7c-be108f1c1dce

Allison, L., \& Monnington, T. (2002). Sport, Prestige and International Relations. Government and Opposition, 37(1), 106-134. https://doi.org/10.1111/1477-7053.00089

Brannagan, P. M., \& Giulianotti, R. (2015). Soft power and soft disempowerment : Qatar , global sport and football' s 2022 World Cup finals. Leisure Studies, 34(6), 703-719. https://doi.org/10.1080/02614367.2014.964291

Brentin, D., \& Tregoures, L. (2016). Entering Through the Sport's Door? Kosovo's Sport Diplomatic Endeavours Towards International Recognition. Diplomacy \& Statecraft, 27(2), 360-378. https://doi.org/10.1080/09592296.2016.1169799

Cha, V. (2016). Role of Sport in International Relations: National Rebirth and Renewal. Asian Economic Policy Review, 11(1), 139-155. https://doi.org/10.1111/aepr.12127

Chadwick, S. (2016). How One Belt, One Road is guiding China's football strategy. Retrieved November 22, 2016, from http://www.scmp.com/sport/soccer/article/2044812/how-onebelt-one-road-guiding-chinas-football-strategy

Chadwick, S., Widdop, P., \& Parnel, D. (2017). A feast for wolves. Retrieved January 6, 2017, from http://www.policyforum.net/a-feast-for-wolves/

China. (2016). China Football for Middle and Long-Term Development Planning.

Duerr, G. M. E. (2016). Civic integration or ethnic segregation? Models of ethnic and civic nationalism in club football/soccer. Soccer \& Society, 970(September), 1-14. https://doi.org/10.1080/14660970.2016.1166767

FIFA. (2016). The FIFA/Coca-Cola World Ranking. Retrieved November 25, 2016, from http://www.fifa.com/fifa-world-ranking/ranking-table/men/ 
Giulianotti, R. (2010). Sociologia do futebol - dimensões históricas e socioculturais do esporte das multidões. São Paulo: Nova Alexandria.

Giulianotti, R. (2015). The Beijing 2008 Olympics: Examining the Interrelations of China, Globalization, and Soft Power. European Review, 23(2), 286-296. https://doi.org/https://doi.org/10.1017/S1062798714000684

Hobsbawm, E. (1991). Nações e Nacionalismo desde 1780. Rio de Janeiro: Terra e Paz.

Hobsbawm, E. (2007). Globalização, democracia e terrorismo. São Paulo: Companhia das Letras.

Hong, F., \& Zhouxiang, L. (2012a). China's sports policy and politics in the post-Beijing Olympics era. International Journal of the History of Sport, 29(1), 184-189.

https://doi.org/10.1080/09523367.2012.634992

Hong, F., \& Zhouxiang, L. (2012b). From Barcelona to Athens (1992-2004): "Juguo Tizhi" and China's quest for global power and Olympic glory. The International Journal of the History of Sport, 29(1), 113-131.

Hong, F., \& Zhouxiang, L. (2012c). Sport in the Great Proletarian Cultural Revolution (1966-1976). International Journal of the History of Sport, 29(1), 53-73.

Hong, F., \& Zhouxiang, L. (2012d). Sports and politics in the 1980s: The Olympic strategy. The International Journal of the History of Sport, 29(1), 74-97.

Hong, F., \& Zhouxiang, L. (2013). The Professionalisation and Commercialisation of Football in China (1993-2013). The International Journal of the History of Sport, 30(14), 1637-1654. https://doi.org/10.1080/09523367.2013.828710

Jing, S. (2016). Fosun deal could kick-start new era for soccer industry. Retrieved November 26, 2016, from http://europe.chinadaily.com.cn/business/2016-01/19/content_23140474.htm

Jourdan, A. (2016). China's Suning buying majority stake in Inter Milan for $\$ 307$ million. Retrieved November 25, 2016, from http://www.reuters.com/article/us-soccer-inter-milan-suningidUSKCNOYRO3T

Kersting, N. (2007). Sport and national identity: A comparison of the 2006 and 2010 FIFA World Cups $^{\text {TM }}$. Politikon, 34(3), 277-293. https://doi.org/10.1080/02589340801962551

Korneeva, V. A., \& Ogurtsov, E. S. (2016). The Politicization of Sports as a Soft Power Public Resource. Indian Journal of Science and Technology, 9(29). https://doi.org/10.17485/ijst/2016/v9i29/89854

Lovisolo, H., \& Soares, A. J. G. (2011). Futebol: construção histórica do estilo nacional. In R. Helal (Ed.), Futebol, jornalismo e ciências sociais: interações (2nd ed., pp. 33-51). Rio de Janeiro: Eduerj.

Nye, J. S. (2004). Soft Power: The Means to Success in World Politics (1st ed.). New York: PublicAffairs.

Nye, J. S. (2012). China and soft power. South African Journal of International Affairs, 19(2), 151155. https://doi.org/10.1080/10220461.2012.706889

People's Daily. (2017). China to build 50,000 football schools by 2025. Retrieved March 3, 2017, from http://en.people.cn/n3/2017/0222/c90000-9181128.html

Plunkett Research. (2016). Plunkett Research Sports Industry. Retrieved November 24, 2016, from https://www.plunkettresearch.com/statistics/sports-industry/

Pollina, E., \& Segreti, G. (2017). Chinese investors looking to postpone closing of AC Milan deal. Retrieved March 3, 2017, from http://www.reuters.com/article/us-acmilan-m-a-closingidUSKBN1672GO

Reuters. (2016). Alibaba discussing FIFA sponsorship : Bloomberg. Retrieved January 20, 2017, from http://www.reuters.com/article/us-alibaba-fifa-idUSKCNOY9255 
Samuel-Azran, T., Yarchi, M., Galily, Y., \& Tamir, I. (2016). Promoting terror or sport? The case of Qatar's international image. American Behavioral Scientist, 60(9), 1101-1115. https://doi.org/10.1177/0002764216632841

Simons, R. (2008). Traves de bambu: como a China aprendeu a amar o futebol. Rio de Janeiro: Record.

Sports, N. (2016). China and Football.

Tan, T.-C., Huang, H.-C., Bairner, A., \& Chen, Y.-W. (2016). Xi Jin-Ping's World Cup Dreams: From a Major Sports Country to a World Sports Power. The International Journal of the History of Sport, 3367(November), 1-17. https://doi.org/10.1080/09523367.2016.1243103

The State Council. (2016). Chinese sports industry aims to reach $\$ 460 \mathrm{~b}$ in 5-year plan. Retrieved November 24, 2016, from http://english.gov.cn/state_council/ministries/2016/05/05/content_281475342468190.htm

TMS, F. (2016). FIFA Transfer Matching System. Retrieved November 24, 2016, from https://www.fifatms.com/wp-content/uploads/2016/06/China_fcbusiness_May2016.pdf van Hilvoorde, I., Elling, a., \& Stokvis, R. (2010). How to influence national pride? The Olympic medal index as a unifying narrative. International Review for the Sociology of Sport, 45, 87102. https://doi.org/10.1177/1012690209356989

Ward, T. (2009). Sport and national identity. Soccer \& Society, 10(5), 518-531. https://doi.org/10.1080/14660970902955455

Zhan, X. (2013). The History and Development Trend of China's Sports Industry Policy, 400-402. 